\title{
HVMANITAS
}

\section{Biblioteca de Alexandria: o Helenismo e a dinâmica cultural dos judeus}

Autor(es): $\quad$ Dias, Geraldo Coelho

Publicado por: Faculdade de Letras da Universidade de Coimbra, Instituto de Estudos
Clássicos

URL

persistente:

DOI: $\quad$ DOI:http://dx.doi.org/10.14195/2183-1718_63_12

Accessed : $\quad$ 26-Apr-2023 13:30:58

A navegação consulta e descarregamento dos títulos inseridos nas Bibliotecas Digitais UC Digitalis, UC Pombalina e UC Impactum, pressupõem a aceitação plena e sem reservas dos Termos e Condições de Uso destas Bibliotecas Digitais, disponíveis em https://digitalis.uc.pt/pt-pt/termos.

Conforme exposto nos referidos Termos e Condições de Uso, o descarregamento de títulos de acesso restrito requer uma licença válida de autorização devendo o utilizador aceder ao(s) documento(s) a partir de um endereço de IP da instituição detentora da supramencionada licença.

Ao utilizador é apenas permitido o descarregamento para uso pessoal, pelo que o emprego do(s) título(s) descarregado(s) para outro fim, designadamente comercial, carece de autorização do respetivo autor ou editor da obra.

Na medida em que todas as obras da UC Digitalis se encontram protegidas pelo Código do Direito de Autor e Direitos Conexos e demais legislação aplicável, toda a cópia, parcial ou total, deste documento, nos casos em que é legalmente admitida, deverá conter ou fazer-se acompanhar por este aviso. 
humanitas

Vol. LXIII

2011 


\title{
BIBLIOTECA DE ALEXANDRIA: O HELENISMO E A DINÂMICA CULTURAL DOS JUDEUS
}

\author{
Geraldo Coelho Dias
}

\begin{abstract}
Resumo
A Biblioteca de Alexandria emblematiza a importância do grego, quando se tornou a língua culta da antiguidade. Por isso, até os judeus, sempre ciosos da superioridade da sua religião e da sua Bíblia, procuraram traduzir para o grego comum - KOINÉ - os seus livros sagrados. Foi esse o princípio das muitas traduções do texto bíblico sagrado, cuja importância literária e até teológica chegou até aos nossos dias e continua essencial para averiguarmos o percurso da Bíblia. Foi o livro apócrifo da "Carta de Aristeu", século II AC, que nos transmitiu a lenda dos 72 sábios, isolados, a fazer cada um a respectiva tradução - Bíblia dos $L X X$ - e como que a justificar a sua revelação para os que, na Diáspora, queriam instruir-se na Palavra do Deus bíblico. Filão de Alexandria narra como os judeus do Egipto veneravam esta tradução e agradeciam a Deus este benefício.

Palavras-chave: Bíblia, Bíblia dos LXX, Carta de Aristeu, Filão de Alexandria.

\footnotetext{
Abstract

The Library of Alexandria exemplifies the importance of the Greek language, after it became the language of culture in Antiquity. For that reason, even Jews, who keenly felt the superiority of their religion and their Bible, sought to translate their sacred books into KOINE Greek. Many other translations of biblical texts followed, the literary and theological importance of which has come down to the present day and remains essential for understanding how the Bible came about. The apocryphal "Letter of Aristaeus", 2nd century AD, transmitted the legend of
} 
the 72 sages, translating the Septuagint in isolation, almost as a revelation for those who, in the Diaspora, wanted to learn the word of God. Philo of Alexandria describes how Egyptian Jews thanked God for this translation.

Key-words: Bible, Septuagint, Letter of Aristaeus, Philo of Alexandria.

\section{I - Introduçãa}

Com Alexandre Magno (336-323), filho de Filipe da Macedónia, a Grécia esforçou-se por espalhar ao longe e ao largo a cultura e a mentalidade humanista dos gregos. As conquistas de Alexandre implantavam, entre os povos conquistados, uma espécie de iluminismo cultural, onde a língua, os costumes e a arte dos gregos ganhavam foros de potência civilizadora. Após a conquista do Egipto, em $332 \mathrm{AC}$, lançaram-se as bases duma nova cidade, aberta aos novos ventos da cultura e da arte gregas, livre das peias da teosofia pagã egípcia e independente do culto dos mortos, que tanto subjugava a vida do povo egípcio.

Na verdade, morto Alexandre, o seu poder é repartido pelos seus dois generais maiores: Seleuco, de quem deriva a dinastia dos Selêucidas, ficará com a parte norte do império, com sede em Antioquia; o sul, com predominância do Egipto, ficará para Ptolomeu I ou Lago, e dará lugar à dinastia dos Lágides. Todos eles se esmeraram em difundir e impor o helenismo, mas serão os Ptolomeus que, junto ao Mediterrâneo, na parte ocidental do Delta do Nilo e em frente da ilha de Faros, irão construir a nova cidade de Alexandria; ela seria como que a sede irradiadora da força do helenismo e da racionalidade humana, que ele impunha. O homem com sua inteligência seria o propulsor e a medida do progresso, da cultura, da religião e da arte. Desse modo e nesta linha de ideias, o grego comum, língua universalizada - KOINÉ - tornou-se o veículo de comunicação universal em todo o Médio Oriente, numa espécie de diálogo cultural entre povo grego e civilizações orientais.

Com o objectivo de promover o helenismo e toda a sua cultura é que se construiu a célebre Biblioteca de Alexandria. Terá sido em meados do século III AC (cerca de 252 AC), quando governava o Egipto Ptolomeu II, Filadelfo. Ali se reuniria todo o empório do saber: literatura, história, filosofia, religião, arte, matemática, astrologia, medicina. Calímaco (305240AC) foi o bibliotecário que elaborou o primeiro catálogo, que ocupava 120 rolos de papiro. Estima-se que chegasse a ter entre 400.000 a 1 milhão 
de papiros. Em 604 DC, foi destruída num incêndio casual. Há pouco, em 2002, foi inaugurada a nova Biblioteca de Alexandria, algo de grandioso senão mesmo megalómano, financiada pela UNESCO e pelo governo egípcio, com o custo total de 200 milhões de Euros. Pretendeu-se que fosse uma biblioteca à altura do seu passado lendário, preparada para as novas tecnologias e com espaço para 8 milhões de livros.

\section{II - Os Judeus e o helenismo}

Em princípio, por força do monoteísmo hebraico e das prescrições da Lei - Torá -, os judeus não só se fecharam ao helenismo como o combatiam. Na verdade, aquela filosofia de vida, a estranheza das categorias lógicas do pensamento aristotélico, a concepção idealista do universo segundo Platão, o ecletismo e sincretismo religioso, tudo isso aparecia aos judeus como algo de oposto à sua religião e à tradição dos antepassados. Por outro lado, a grandeza e beleza dos edifícios urbanos, como hipódromo, teatro, ginásio, tudo isso parecia um atentado à grandeza, beleza e santidade do Templo de Jerusalém. Por isso, dado a ocupação dos selêucidas invasores, os judeus revoltaram-se no tempo de Antíoco IV, Epífanes (174-164AC), e isso levou, de seguida, à guerra dos Macabeus. Todavia, entre o I século AC e o I século DC, o helenismo conseguiu ganhar foros de cidadania em Jerusalém, e a obra do rei Herodes, o Grande, é disso significativa demonstração. Até o NT fala de helenistas (gregos), certamente judeus que viviam em Jerusalém e se tinham helenizado (Act. 6,1; 9,29; 11,20).

Todavia, não podemos ignorar que, desde o Cativeiro de Babilónia, em 586 AC, os judeus conheceram o fenómeno da emigração ou Diáspora, que determinou a fixação de comunidades judaicas em terras pagãs ou helenistas numa espécie de sementeira pelo mundo. A Diáspora - essa sementeira étnico-cultural - contribuirá, pois, em grande medida, para essas comunidades entre pagãos se abrirem à cultura helenista, pelo menos a nível linguístico e cultural. Será, sobretudo, no Egipto que isso mais se evidenciará com a dinâmica cultural dos judeus, traduzindo a Torá ou Lei para a língua grega por causa dos muitos judeus que tinham perdido o contacto com a língua mãe hebraica.

De facto, desde longa data, séculos V-IV A.C., ou período persa, havia uma comunidade judaica de soldados e comerciantes na ilha de Elefantina, em pleno rio Nilo, frente a Assuan, cuja vida nos é conhecida pelos papiros de Elefantina, com o célebre templo de Yaho, forma abreviada de Javé. A 
maior parte da documentação está escrita em aramaico, e apesar de mostrar, por parte dessa comunidade, uma grande fidelidade religiosa, testemunha também dificuldades de relacionamento com a população local egípcia e aponta até para uma certa hostilidade, que terá levado à destruição do templo de Yaho. O isolamento e a distância, em relação a Alexandria, parecem ter livrado esta comunidade judaica da tentação do helenismo.

Em contrapartida, sabemos que, em Alexandria, vivia uma grande comunidade judaica, que não pôde esquivar-se à influência helenística, quer do ponto de vista da língua, quer do pensamento e até do modo de viver.

\section{III - Helenismo e Bíblia}

Os judeus consideram sagrado o texto hebraico da sua Bíblia, a "Biblia massorética", como se ele tivesse sido revelado; mas, sem dúvida, não houve um texto único da Bíblia, e sim um texto plural. Contudo, no Cânone hebraico da Bíblia, isto é, no catálogo dos seus livros sagrados, só são contados, como tais, aqueles que obedecerem a 3 critérios: 1 - Estarem escritos em hebraico; 2 - Não conterem erros contra a tradição judaica; 3 - Serem expressamente aprovados pelos mestres. Foi o Concílio de Jâmnia, cerca do ano 90 DC, que definiu tais parâmetros e contou apenas 39 livros da Bíblia Sagrada, na medida em que o $40^{\circ}$, escrito pelo Messias, quando viesse, levaria a Bíblia à plenitude e perfeição do número 40. Talvez não valha a pena expor aqui a complexidade da escrituração da Bíblia Hebraica e do seu reconhecimento, afirmando-se apenas a sua realidade sacral. $\mathrm{Na}$ verdade, a implementação da Bíblia foi um trabalho árduo, de longa duração, por etapas, que só no Cativeiro de Babilónia (586-538) e depois foi levado a cabo por obra de sacerdotes e escribas. A Bíblia hebraica estaria completada aí entre os séc. III-II AC. Por aqui se poderá imaginar como foi difícil e longa também a empresa da tradução da Bíblia, do hebraico para o grego da Koiné, tanto mais que muitos judeus da Diáspora, no Egipto, já não falavam nem entendiam o hebraico, língua sagrada, suplantada que fora entre o povo pelo aramaico, e, à tradução grega, não era reconhecido o princípio da revelação ${ }^{1}$.

${ }^{1}$ Trebolle Barrera, Julio, A Bíblia Judaica e a Bíblia Cristã. Introdução à história da Bíblia, 2a ed., Petrópolis, 1999. 
1 - Tradução da "Bíblia dos LXX". Antes de mais, a explicação por que se chama "Bíblia dos LXX". Isso baseia-se num livro apócrifo, datado do s. II AC, chamado "Carta de Aristeu", sem dúvida um escrito apologético para defender a autoridade, senão mesmo a revelação da dita tradução. Trata-se da lenda acerca dos 72 sábios enviados de Jerusalém, seis por cada uma das doze tribos de Israel $(6 \times 12=72 / 70)$, que, separados, cada um em sua tenda na ilha, apresentaram uma tradução absolutamente igual. Terá sido no tempo de Ptolomeu II, Filadelfo (285-246AC). Inicialmente, só foi traduzido o Pentateuco ou 5 livros da Lei, mas depois seguir-se-iam os outros. Sabemos que, no fim do s. II AC, o neto do Seracida (Eclesiástico), traduzia a obra do avô, informando que já corriam em grego o Pentateuco, os Profetas, e outros livros, segundo o Cânone hebraico (Si. - Prol. 8-10). No prólogo, que antecede a tradução do Eclesiástico, ou Ben Sirac, o único livro de que se conhece o nome do autor, o neto, que o traduziu, deixou bem claro que, ao chegar ao Egipto, "observou uma diferença não insignificante na instrução" e foi isso que o determinou a "concluir e publicar esta obra, para utilidade dos que, em terra estrangeira, querem instruir-se, reformar os seus costumes e viver segundo a Lei”.

Esta tradução dos LXX engloba sete livros apócrifos, que não eram conhecidos do hebraico, que os católicos chamam "Deutero-canónicos" e os protestantes "Pseudo-epígrafos". São eles: Judite, Tobias, $1^{\circ}$ e $2^{\circ}$ dos Macabeus, Sabedoria, Eclesiástico ou Ben Sirac, Baruc, com mais alguns fragmentos de Ester e Daniel; todos eles são, indiscutivelmente, tardios e, muitas vezes, rotulados de apócrifos.

No princípio do s. I DC, Filão de Alexandria narra como os judeus do Egipto vinham, anualmente, em frente da ilha de Faros "venerar o lugar onde, pela primeira vez, brilhou a luz desta tradução e agradecer a Deus este benefício antigo e sempre novo" (Vita Moisis, 2,41).

Há muitas discussões sobre quem mandou fazer a tradução e para quê. Sabe-se que segue um texto bastante diferente do hebraico-massorético, tanto mais que, pelas descobertas de Qumran, sabemos, hoje, que havia diversos e diferentes textos hebraicos. Como quer que seja, esta tradução grega não é um bloco homogéneo e uniforme, mas o ponto de chegada, a recolha dum longo e plural esforço, até porque se foram descobrindo fragmentos gregos, que revelam original diferente dos LXX.

$\mathrm{Na}$ tradução, primeiro foi o Pentateuco, depois os Profetas, os Hagiógrafos ou Ketubyim, os Provérbios, Job, etc. O Livro de Daniel, escrito por volta de $164 \mathrm{AC}$, foi traduzido para grego de forma bastante 
livre. Quanto aos Salmos, a versão dos LXX é bastante literal em relação ao texto hebraico, e estabelece uma numeração diferente. Em Qumran (Gruta XI), o Saltério ali encontrado mistura salmos canónicos com salmos não canónicos. As traduções latinas posteriores seguiram o texto dos LXX.

Pode, pois, dizer-se que a tradução dos LXX foi-se fazendo e por mãos diferentes em papiros e depois em códices, que, posteriormente, já no adiantado século IV-V do Cristianismo, serão conhecidos como Codex Sinaiticus, Alexandrinus, Vaticanus. Claro que, não raro, esta tradução acrescentou e fez paráfrases ao hebraico massorético, a "Hebraica veritas" de S. Jerónimo (fragmentos gregos de Ester, suplementos gregos de Daniel; oração de Azarias; Cântico dos três jovens na fornalha; história de Susana, de Baal e do dragão), mas permite afirmar que também havia textos hebraicos diferenciados, como revelaram os documentos bíblicos de Qumran $^{2}$. Tudo isso proporcionou um enriquecimento dos textos bíblicos, que os primeiros cristãos não desprezaram e aproveitaram até na exegese e interpretação da SE. Aliás, esta tradução grega permitiu que se salvassem livros ou escritos em hebraico ou em grego, que vieram alargar o âmbito da Bíblia hebraica com mais 7 livros, chamados Deutero-canónicos, ou Pseudo-Epígrafos, segundo os Protestantes, para não falar de outros textos claramente espúrios e apócrifos, como a Oração de Manassés e o $2^{\circ}$ e $3^{\circ}$ livros de Esdras. Alguns destes livros são nitidamente helenistas, como o Livro da Sabedoria, outros dão a conhecer factos da história hebraica $\left(1^{\circ} \mathrm{e}\right.$ $2^{\circ}$ dos Macabeus, Eclesiástico ou Ben Sirac, Judite, Tobias, Sabedoria, Baruc), que, de outro modo, se teriam perdido e, hoje, servem para alentar a sobrevivência de Israel. São eles que levam o Cânone Católico da Bíblia a contar 46 livros no AT. A tradução dos LXX esteve, além disso, na origem das traduções de Áquila, Teodocião, Símaco e das Hexáplas de Orígenes, e animou a Escola teológica cristã de Alexandria entre os séculos III-V da Era Cristã, fomentando uma exegese bíblica espiritualizante e alegórica, muitas vezes em diferença e contraste com a Escola Antioquena, realista e humanista, o que se verifica principalmente na história das heresias. A tradução grega dos LXX foi, de facto, uma realização importantíssima para a difusão e conhecimento da Sagrada Escritura dos judeus; ela não teria sido possível sem o contributo do helenismo.

${ }^{2}$ Para compreender os Manuscritos do Mar Morto, Coordenação de Jaime Vásquez Allegue, Coimbra, Gráfica de Coimbra, 2005 (Tradução do espanhol). 
Bem pode, por conseguinte, dizer-se que "o homem criou a Bíblia" 3 , tantos e tais são os problemas de crítica textual e literária, que ela nos apresenta nos diversos idiomas mais antigos.

2 - Filão de Alexandria (20 ac-50 dc). Trata-se dum bom exemplo de judeu helenizado ${ }^{4}$. Era um judeu crente e procurava, de facto, conciliar a filosofia greco-platónica com a Bíblia, principalmente o Pentateuco, segundo método alegórico, vindo a influenciar Padres cristãos, como Orígenes e Clemente de Alexandria, com a doutrina do Lógos, isto é, da conciliação entre ciência e religião. Contam-se 36 escritos ou obras suas, entre as quais o "De vita contemplativa", um dos mais influentes para os movimentos ascéticos e monásticos antigos (Terapeutas) ${ }^{5}$, mas até livros de ciência como o "De agricultura".

3 - Flávio Josefo (37-100 DC). Outro helenista famoso foi um judeu que, na luta do seu povo contra os romanos, se soube, camaleonicamente, adaptar aos invasores e depois se soube defender, descrevendo a guerra travada e dando uma visão grandiosa das instituições hebraicas. Sem renegar o judaísmo, aceitou o helenismo, e foi em grego que escreveu as suas obras, posteriormente muito conhecidas na tradição cristã: De bello judaico; Antiquitates judaicae; Autobiografia.

CONCLUSÃO. Todo este movimento cultural, juntamente com o fenómeno da Diáspora, é que fez chegar a Bíblia, com toda a complexidade da sua redacção e tradução, ao movimento do Helenismo. Isto, porém, não teria sido possível sem o Pan-Helenismo e a ideia inicial e dinâmica, que levou à construção da lendária Biblioteca de Alexandria - coração cultural da humanidade na antiguidade -. Isso enalteceu de tal modo o Pan-Helenismo, que até levou os nobres romanos a usar o grego como língua erudita, pois, como dizia o aforisma antigo, "Gaecia victa vixit victores", isto é, a Grécia vencida é que, afinal, venceu os vencedores revelando-lhes a beleza da sua língua e a grandeza da sua cultura.

${ }^{3}$ Palu, André - E o homem criou a Bíblia. De Heródoto a Flávio Josefo, Lisboa, Instituto Piaget, 2000 (Trad. Do francês).

${ }^{4}$ Daniélou, Jean - Philon d'Alexandrie, Paris, Librairie Arthème Fayard, 1958.

${ }^{5}$ Filón de Alejandria - Los terapeutas. De vita contemplativa, Salamanca, Ediciones Sigueme, 2005. 